УДК 336.1

Олена Стащук,

доктор економічних наук, професор,

Волинський національний університет імені Лесі Українки, кафедра фінансів,

м.Луцьк; ORCID ID: 0000-0003-2622-7353 e-mail: Staschuk.Olena@vnu.edu.ua

https://doi.org/10.29038/2786-4618-2021-01-98-104

\title{
БЮДЖЕТНА ЕФЕКТИВНІСТЬ ТЕРИТОРІЙ В УМОВАХ ДЕЦЕНТРАЛІЗАЦІЇ
}

У статті узагальнено науково-теоретичні підходи до визначення понять ефективність і децентралізація. Акцентовано увагу на проблемних аспектах формування і використання фінансових ресурсів органів місцевого самоврядування. На основі дедуктивного методу наукових досліджень та з урахуванням власного розуміння економічного змісту категорії “ефективність", обгрунтовано визначення поняття бюджетної ефективності територій в умовах децентралізації та запропоновано механізм їі забезпечення. До такого механізму рекомендовано внести напрями забезпечення ефективності доходів територіальних громад, організаційноінституційне підгрунтя, напрями забезпечення ефективності видатків територіальних громад. Проаналізовано вплив дохідної бази територіальних громад на їх бюджетну ефективність. Обгрунтовано, що передумовою забезпечення бюджетної ефективності територій є фінансова незалежність органів місцевого самоврядування від дій і рішень державної влади у сфері фінансів.

Ключові слова: бюджетна ефективність територій, децентралізація, доходи і видатки місцевих бюджетів, фінансові ресурси місцевого самоврядування.

Елена Стащук, доктор экономических наук, профессор, Волынский национальный университет имени Леси Украинки, кафедра финансов, г. Луцк

\section{БЮДЖЕТНАЯ ЭФФЕКТИВНОСТЬ ТЕРРИТОРИЙ В УСЛОВИЯХ ДЕЦЕНТРАЛИЗАЦИИ}

В статье обобщены научно-теоретические подходы к определению понятий эффективность и децентрализация. Акцентировано внимание на проблемных аспектах формирования и использования финансовых ресурсов органов местного самоуправления. На основе дедуктивного метода научных исследований и с учетом собственного подхода к определению экономического содержания категории “эффективность”, обоснованно собственное определение понятия бюджетной эффективности территорий в условиях децентрализации и предложен механизм ее обеспечения. К такому механизму рекомендуется внести: направления обеспечения эффективности доходов территориальных общин, организационноинституциональную основу, направления обеспечения эффективности расходов территориальных общин. Проанализировано влияние доходной базы территориальных общин на их бюджетную эффективность. Обосновано, что предпосылкой обеспечения бюджетной эффективности территорий является финансовая независимость органов местного самоуправления от действий и решений государственной власти в сфере финансов.

Ключевые слова: бюджетная эффективность территорий, децентрализация, доходы и расходы местных бюджетов, финансовые ресурсы местного самоуправления.

Olena Stashchuk, Doctor of economics, Professor, Lesya Ukrainka Volyn National University, Department of Finance Lutsk 


\section{BUDGET EFFICIENCY OF TERRITORIES WITHIN THE DECENTRALIZATION}

One of the key of territories socio-economic development and strengthening of local self-government in Ukraine is to provide the territories budgetary efficiency. The lack of necessary financial providing for state delegated powers and the inability to financing its own development strategies show the inefficient revenue generation and expenditure financing at the local level. It indicates the incompleteness of the transformation processes in our country. So, it is necessary to deeper investigation of the specific aspects of decentralization in Ukraine. The purpose of this article is to investigate the influence of decentralization on the local self-government budgetary effectiveness. It is important to form economic essence of the territories efficiency category within the decentralization and to form the mechanism of its providing.

Budget efficiency of territories is a complex economic category that includes the efficiency of local budgets revenue and expenditure. Expenditure are very important as the way of satisfaction of socio-economic functions of local self-government and revenue are the source of this expenditure financing. According to the organizational view the main bases to budget efficiency of territories is the financial independence of local authorities, which can be achieved through the effective decentralization. On the financial side, budgetary efficiency is the necessary financial resources to financing the current and development expenditure. This creates the preconditions for improving the territorial community's development level, its competitiveness and quality of local resident's life.

In Ukraine the decentralization process has not provided the expected territories budget efficiency. There are such problems as lack of budget funds, miscalculations in the state and local taxation system, passive investment policy of local governments. The mechanism of the territories budget efficiency providing in the conditions of decentralization should includes the directions of increase of incomes and expenses efficiency, the corresponding the organizational, legal and institutional basis. It is important to provide the social and economic development of territories. The idea of forming the mechanism of territories budget efficiency is the improving the own financial policy of local selfgovernments. No qualitative changes are possible in condition of the passive financial and investment police of local governments.

For the territories development it is important to stimulate the business activity, development of public-private partnership with the purpose to increasing of budget revenue. It is also necessary to increase the efficiency of formation, distribution and usage of budgetary recourses through the improvement of local budgets revenue and expenditure planning process. The best tools for this reason are economic and mathematic modeling. It will provide the concordance between the processes of formation and usage of territories financial resources and the main goals of local governments functioning and development. Through the mechanism of providing the territories budget efficiency in the context of decentralization it is possible to improve the policy of local financial management and achieve the territories socio-economic development.

Key words: budget efficiency of territories, decentralization, local budgets revenue and expenditure, local governments, financial resources.

Постановка проблеми та їі значення. На сьогодні, в нашій державі успішно реалізується механізм передачі владних повноважень та фінансових ресурсів на місця і вже $\epsilon$ позитивні результати підвищення бюджетної ефективності територіальних громад. Однак, особливості розвитку держави, місцевого самоврядування та суспільства в конкретному історичному періоді вносять свої корективи у функціонування системи фінансових відносин, котра має бути гнучкою $\mathrm{i}$ адаптуватися до подолання можливих негативних ендогенних та екзогенних чинників впливу. Крім цього, питання збереження тенденції залежності територій від центру, а також наявність значної невідповідності джерел фінансових ресурсів і обсягу видатків місцевих бюджетів обумовлюють актуальність проблематики бюджетної ефективності територій в сучасних умовах зовнішніх i внутрішніх викликів та загроз.

Аналіз останніх досліджень і публікацій. Тематика бюджетної ефективності територій, як і децентралізації загалом, завжди була i залишається в полі зору вітчизняних вчених і практиків, законотворців, представників державних органів влади і органів місцевого самоврядування, а також пересічних громадян і місцевих активістів. Зокрема, теоретико-методичні та практичні засади ефективності місцевих бюджетів в контексті реалізації фінансової децентралізації висвітлені в працях відомих науковців, серед яких С. Буковинський, В. Власюк, В. Зайчикова, У. ВатаманюкЗелінська, О. Кириленко, І. Луніна, Ю. Радилецький, Л. Тарангул та багато інших. Однак, 
потребують удосконалення й поглиблення науково-теоретичні та методологічні засади забезпечення бюджетної ефективності територій на сучасному етапі розвитку нашої держави.

Мета і завдання статті. Головною метою наукової статті є удосконалення комплексного підходу до забезпечення ефективності місцевих бюджетів в напрямку зміцнення фінансової бази територіальних громад, досягнення їх конкурентоспроможності й сталого соціально-економічного розвитку.

Виклад основного матеріалу дослідження 3 повним обгрунтуванням отриманих наукових результатів. В сучасній економічній науці є багато наукових праць, в яких учені прямо чи опосередковано обгрунтовують окремі аспекти децентралізації та іiі впливу на бюджетну ефективність територій, звужуючи та розширюючи межі предмету наукового дослідження. Зокрема, глибоко висвітлені такі поняття як власне “децентралізація” [3, с. 61-62] та ії різновиди (фінансова, бюджетна, фіскальна), а також “фінансова незалежність” [2, с. 324] й “фінансова автономія” [4, с. 9091], які й дозволяють забезпечувати ефективність формування і використання бюджетних ресурсів.

Щодо “ефективності” загалом, то серед низки наукових підходів до іiі трактування, найпоширенішим $є$ визначення розглядуваної дефініції через відношення результату до витрат, понесених на його отримання. При цьому, розрізняють економічну, інноваційну, соціальну, правову, а також ефективність суспільного виробництва тощо [6].

Принагідно відзначимо, плюралізм наукових поглядів на сутність категорій “ефективність” та “децентралізація” обумовлений їхнью багатогранністю й багатовимірністю, а також особливостями гносеології об'єкта наукових досліджень учених і практиків.

Беручи за основу причинно-наслідковий зв'язок децентралізації та бюджетної ефективності територій, вважаємо за необхідне розглянути фінансову децентралізацію, оскільки саме вона $є$ першопричиною бюджетної ефективності, котра проявляється в зміцненні фінансової основи місцевого самоврядування та досягненні цілей соціально-економічного розвитку територій. Так, під фінансовою децентралізацією в широкому розумінні вважатимемо - сукупність власних i делегованих повноважень органів місцевого самоврядування з приводу формування і використання відповідних локальних фінансових ресурсів в напрямку якнайповнішого задоволення потреб місцевих жителів. У вузькому розумінні, вважатимемо фінансовою саме бюджетну децентралізацію, під якою розумітимемо систему прав, дій і рішень місцевих властей, спрямованих на планування, розподіл і використання коштів місцевих бюджетів 3 урахуванням соціально-економічних, географічних і суспільно-психологічних особливостей розвитку територій. Принагідно відзначимо, 3 метою уникнення тавтології, в дослідженні будемо вживати термін децентралізації, розуміючи при цьому їі бюджетну форму.

Так, децентралізація, що розпочалася в Україні ще у 2014 р. внесла свої корективи у процеси формування і використання фінансових ресурсів органів місцевого самоврядування. Однак, про ефективність функціонування місцевих бюджетів не йдеться. Здавалося б, розширення дохідної бази територіальних громад та удосконалення фінансування відповідних видатків мали б сприяти розвитку місцевих громад та покращення умов життя місцевих жителів. Проте, на практиці, можна спостерігати ті самі проблеми, котрі були актуальними й до проведення децентралізації. Зупинимось детальніше на окремих із них.

Наприклад, розширення дохідної бази адміністративно-територіальних одиниць, що відбулося за рахунок перерозподілу окремих загальнодержавних податків і зборів на користь місцевих бюджетів та введення нових видів податкових платежів на локальному рівні не сприяло підвищенню бюджетної ефективності, а відтак, забезпеченню достатнього обсягу фінансових ресурсів для фінансування соціально-економічних та інвестиційних видатків.

Вагомим джерелом доходів місцевих бюджетів став податок на доходи фізичних осіб. Однак, в практиці його адміністрування $є$ певні нюанси, які перешкоджають виконанню ним головної функції - збільшення фіскальних потужностей територій. Це те, що він стягується за місцем знаходження податкового агента - юридичної особи, а не за фактичним місцем його реєстрації. Відтак, місцеві бюджети, де фактично зареєстрований суб'єкт господарювання, втрачають фінансові ресурси. Схожі наслідки має ситуація, коли мова йде про тіньовий сектор економіки. Використання практики 
виплати заробітної плати в конвертах спотворює реальний стан бази оподаткування, значно звужуючи іiі.

Що стосується акцизного податку з реалізації підакцизних товарів, який був запроваджений 3 метою посилення фіскальної самостійності місцевих властей, він став справжнім вимірником соціально-економічних дисбалансів розвитку територій. Справа в тому, що за аналізом справляння цього податку вдалося встановити певні особливості його адміністрування. Це те, що головними його реципієнтами стали бюджети приміських територій та територій з розвинутим транспортним сполученням - а точніше - території з наявністю головних платників розглядуваного податку (ними $\epsilon$ автозаправні станції) [5, с. 33].

Досліджуючи місцеві податки і збори, можна констатувати, що вони підвищили бюджетну ефективність територій: їх склад розширено, а фіскальна роль у наповненні місцевих бюджетів зросла, що свідчить про посилення фінансової незалежності територій за рахунок цього фінансового інституту. Щоправда, окремі аспекти місцевого оподаткування та адміністрування місцевих податків і зборів ще потребують удосконалення.

Головною проблемою функціонування видатків була й залишається невідповідність між реальним та необхідним обсягом фінансового забезпечення делегованих повноважень місцевих властей. Так, на місцевий рівень передані чи не найважливіші завдання соціально-економічного характеру та відповідні фінансові ресурси. Проте, на практиці їх не вистачає для повноцінного фінансування зазначених видатків. Наприклад, освітня субвенція покриває лише оплату праці педагогічного персоналу. Натомість всі інші видатки, пов'язані з функціонуванням галузі фінансуються за рахунок доходів загального фонду бюджетів органів місцевого самоврядування. Схожа ситуація й із субвенцією на охорону здоров'я, котрої також не вистачає на фінансування усіх потреб, передбачених договорами між медичними закладами і Національною службою охорони здоров'я стосовно медичного обслуговування населення за програмою державних гарантій [1].

Необхідність такого “відволікання" коштів призводить до звуження фінансової самостійності місцевих властей, а відтак суперечить головній меті децентралізації та не сприяє розвитку територій. Окрім цього, делеговані видатки соціального характеру вимагають перманентного зростання дохідної бази місцевих бюджетів, економічне підгрунтя для якої, подекуди, відсутнє [7].

Зазначене проявляється у неможливості повномасштабного фінансування власних повноважень у сфері інвестицій. Відтак, залишається актуальною дилема пасивної інвестиційної політики органів місцевого самоврядування, котра свідчить про бюджетну неефективність територій. Більшість капітальних видатків місцевих бюджетів спрямовані на реконструкцію і ремонт, в той час, коли інфраструктурні проекти місцевого значення залишаються недофінансованими.

Беручи за основу все вищесказане, а також власне розуміння бюджетної ефективності та фінансової децентралізації у вузькому значенні, розглядатимемо іiі як сукупність напрямів підвищення результативності формування і використання фінансових ресурсів на локальному рівні, що проявляється у досягненні сталого економічного зростання, підвищенні конкурентоспроможності та самодостатності адміністративно-територіальних одиниць й, врешті-решт, у покращенні якості життя громадян. Розрізнятимемо бюджетну ефективність за доходами і за видатками як головними складовими місцевих бюджетів та агрегованими фінансовими інститутами, а в механізм реалізації бюджетної ефективності в умовах децентралізації, окрім зазначеного, вмістимо нормативно-правове та організаційно-інституційне підгрунтя, кількісні показники, а також наслідки для суспільства i держави (рис. 1).

При цьому, вважаємо, що передумовою забезпечення бюджетної ефективності територій $\epsilon$ фінансова незалежність органів місцевого самоврядування від дій і рішень державної влади у сфері фінансів. Це означає, що представники місцевих властей мають широкі повноваження щодо формування власних доходів та фінансування видатків залежно від першочергових потреб громадян і економічного розвитку конкретних територій. Саме за таким вектором ми вбачаємо можливість забезпечення бюджетної ефективності в умовах децентралізації. Відтак, за відсутності дублювання повноважень на різних рівнях урядування і повноцінного фінансового забезпечення делегованих державою завдань, органи місцевого самоврядування мають зосередитись на власній фінансовій політиці, спрямованій на підвищення бюджетної ефективності. Бо, на сьогодні, локальну бюджетну 
активність можна вважати низькою: заходи зі зміцнення власної фінансової бази територій, в тому числі й створені в процесі фіскальної децентралізації, реалізуються не достатньо.

Вважаємо за необхідне віднайти стабільні джерела власних доходів територій за рахунок розвитку малого i середнього бізнесу в тих галузях, які $\epsilon$ доступними, пріоритетними й затребуваними на окремих територіях. Це можуть бути зелений туризм та інші види соціальнокультурних послуг. 3 метою їх розвитку необхідно використати усі можливі організаційно-правові та фіскальні інструменти. Це дозволить збільшити усі пов'язані 3 підприємництвом податкові надходження та покращити місцеву інфраструктуру.

Перспективним й таким, що практично не використовується в Україні, є напрям підвищення бюджетної ефективності територій залученням приватного оператора до фінансування розвитку галузей житлово-комунальної господарства. Відбір інвестора здійснюється на конкурсній основі, за чітко визначеним алгоритмом, тому є можливість обрати найвигідніший для територіальної громади проект. При цьому, незалежно від виду проекту інвестор перманентно вносить до місцевого бюджету визначену і обгрунтовану плату, що $\epsilon$ альтернативним джерелом наповнення бюджету території, а фінансування модернізації об'єкта сприяє удосконаленню місцевої інфраструктури.

Зростання доходів місцевих бюджетів прямо пропорційно впливає на збільшення видатків. Однак, їх фінансування має здійснюватися за принципом відповідності потребам місцевих жителів 3 метою якнайповнішого їх задоволення. Крім того, вважаємо за необхідне удосконалити процес планування поточних і видатків розвитку застосуванням інструментарію економіко-математичного моделювання, що дозволить встановити зв'язок цілей 3 результатами $\mathrm{i}$ спрогнозувати або відкоригувати їх обсяги і напрями в залежності від можливих схем чи сценаріїв фінансування, виокремлених за результатами моделювання.

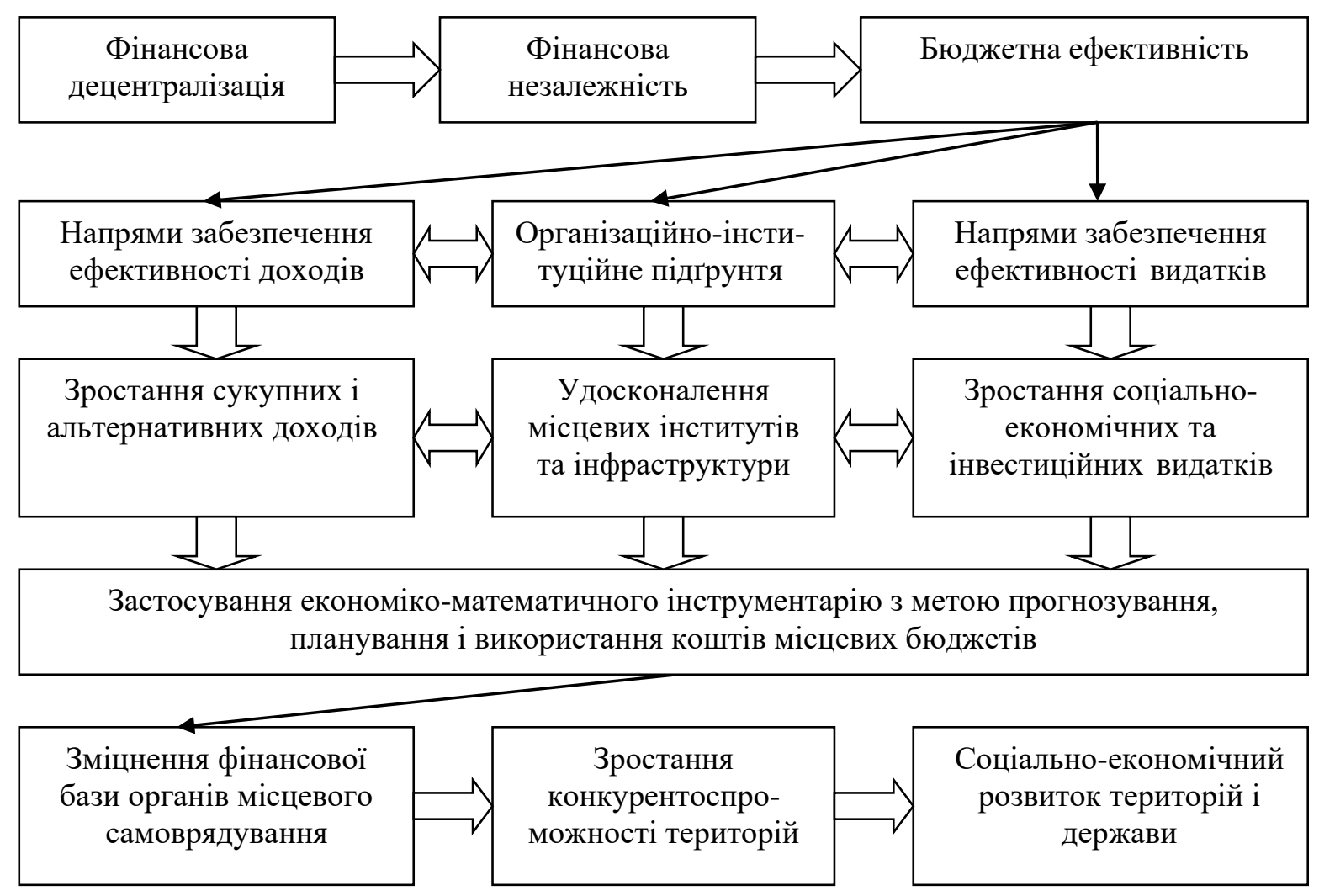

Рис. 1. Механізм забезпечення бюджетної ефективності в умовах децентралізаиії

Відтак, до напрямів забезпечення бюджетної ефективності територій сміло можна зарахувати: 
1) За доходами:

- використання переваг місцевої ресурсної бази для розширення джерел доходів місцевих бюджетів (наприклад, розвиток зеленого туризму);

- стимулювання розвитку малого i середнього бізнесу використанням різноманітних інструментів преференційного оподаткування, а також організацією грантової форми підтримки окремих галузей та видів діяльності;

- залучення приватного сектору до фінансування розвитку локальної інфраструктури, використанням різноманітних схем публічно-приватного партнерства;

- застосування механізмів економіко-математичного моделювання 3 метою прогнозування i планування обсягів доходів місцевих бюджетів та оцінки їх співвідношення із цілями розвитку територій.

2) За видатками:

- наявність достатнього обсягу фінансових ресурсів для здійснення соціально-значущих i капітальних видатків;

- фінансування територій за принципом відповідності потребам місцевих жителів;

- запровадження економіко-математичного обгрунтування бюджетних програм 3 чітким формуванням цілей, обсягами фінансування та бажаними результатами.

Реалізація зазначених напрямів зміцнення фінансової бази $\epsilon$ основою зростання конкурентоспроможності та соціально-економічного розвитку територій, що обумовить “приплив" капіталу та трудових ресурсів з інших регіонів і держав. Щоправда, для цього необхідно створити належне організаційно-інституційне поле, яке, на наш погляд, має вміщувати:

- необхідність забезпечення прозорості планування та виконання місцевих бюджетів;

- посилення інформаційно-технічної бази бюджетного процесу;

- розробка нормативно-методичної та методологічної основи для реалізації публічноприватного партнерства та розвитку нових форм бізнесу;

- проведення ефективної кадрової політики та підвищення кваліфікації працівників системи управління бюджетними ресурсами;

- здійснення дієвого бюджетного контролю за формуванням і використанням фінансових ресурсів місцевого бюджету;

- налагодження способів співпраці й взаємодії місцевої влади 3 громадськістю, а також організація громадських слухань стосовно важливих питань розвитку територій;

- узгодження місцевої та державної бюджетної політики.

Ці заходи значно спростять процес планування доходів і фінансування видатків для працівників системи управління місцевими фінансами, підвищать прозорість бюджетного процесу на локальному рівні та довіру місцевих жителів до представників органів місцевого самоврядування, сприятимуть покращенню суспільного клімату в межах певного ареалу загалом.

Що стосується кількісної оцінки бюджетної ефективності територій в умовах децентралізації, вважаємо за доцільне використовувати горизонтальний, вертикальний, трендовий аналіз, а також економетричні методи і моделі. Так, наприклад, про ефективність формування та використання бюджетних ресурсів адміністративно-територіальних одиниць можна зробити висновки за такими показниками і тенденціями як:

- перевищення темпів зростання сукупних доходів над видатками;

- збільшення частки власних доходів у структурі доходів місцевих бюджетів;

- зростання питомої ваги інвестиційних видатків і доходів у динаміці;

- переважання частки видатків розвитку над питомою вагою видатків соціально-економічного характеру;

- досягнення узгодженості цілей бюджетної політики територій з обсягами доходів і видатків у межах економіко-математичного моделювання.

Зазначені напрями забезпечення бюджетної ефективності, показники оцінювання та організаційно-інституційне підгрунтя можуть бути уточнені чи доповнені у відповідності до конкретних цілей бюджетної політики органів місцевого самоврядування й 3 урахуванням 
екзогенних та ендогенних чинників впливу, котрі змінюються залежно від рівня соціальноекономічних та суспільно-політичних відносин.

Висновки i перспективи подальших досліджень. Таким чином, забезпечити бюджетну ефективність територій в умовах децентралізації можливо реалізацією комплексу заходів $з$ модернізації управління доходами і видатками місцевих бюджетів за умови фінансової незалежності та фінансово-інвестиційної активності органів місцевого самоврядування. При цьому, потрібно створити належне організаційно-інституційне підгрунтя. Кінцевими цілями досягнення бюджетної ефективності територій $€$ підвищення їх конкурентоспроможності та соціальноекономічний розвиток.

\section{Джерела та література}

1. Асоціація звернулася до Уряду та Мінфіну щодо проблемних питань бюджетів ОТГ у 2020-2021 роках URL: http://www.hromady.org. (дата звернення 15.02.2021). $384 \mathrm{c}$.

2. Кириленко О. П. Місцеві бюджети України (історія, теорія, практика ) : Монографія. К.: НIOC, 2000.

3. Луніна І. Бюджетна децентралізація в Україні у контексті європейських тенденцій. Збірник наукових праць Національного університету державної податкової служби України. 2016. № 2. С. 155-171.

4. Кравченко В. І. Місцеві фінанси України: навч. посібник. К.: Знання, 1999. 487 с.

5. Радилецький Ю. Проблеми наповнення місцевих бюджетів в Україні в контексті фінансової децентралізації. Світ фінансів. 2017. № 2 (51). С. 29-41.

6. Череп А., Стрілець $€$. Ефективність як економічна категорія URL:http://www.economy.nayka.com.ua/?op=1\&z=1727 (дата звернення 15.02.2021).

7. Stashchuk O., Khomiuk N., Bochko O., Pavlikha N., Demchuk A., Shmatkovska T., Naumenko N. Economic modeling of sustainable rural development under the condition of decentralization: a case study of Ukraine. Scientific Papers. Series "Management, Economic engineering in agriculture and rural development", 2020. Vol. 20, Issue 3.

\section{References}

1. Asotsiatsiya zvernulasya do Uryadu ta Minfinu shchodo problemnykh pytan' byudzhetiv OTH u 2020-2021 rokakh (2020) [The Association appealed to the Government and the Ministry of Finance on problematic issues of OTG budgets in 2020-2021]. Retrieved from:http://www.hromady.org. [in Ukrainian].

2. Kyrylenko O. P. (2000). Mistsevi byudzhety Ukrayiny (istoriya, teoriya, praktyka ) : Monohrafiya. [Local budgets of Ukraine (history, theory, practice): Monograph.] K.: NIOS, 384 p. [in Ukrainian].

3. Lunina I. Byudzhetna detsentralizatsiya v Ukrayini u konteksti yevropeys'kykh tendentsiy (2016). [Budget decentralization in Ukraine in the context of European trends]. Zbirnyk naukovykh prats' Natsional'noho universytetu derzhavnoyi podatkovoyi sluzhby Ukrayiny - Collection of scientific works of the National University of the State Tax Service of Ukraine., 2. P. 155 - 171. [in Ukrainian].

4. Kravchenko V. I. (1999). Mistsevi finansy Ukrayiny: navch. Posibnyk [Local finances of Ukraine: textbook]. K.: Znannya, 487 p. [in Ukrainian].

5. Radylets'kyy YU (2017). Problemy napovnennya mistsevykh byudzhetiv v Ukrayini v konteksti finansovoyi detsentralizatsiyi [Problems of filling local budgets in Ukraine in the context of financial decentralization] Svit finansiv - The world of finance, 2 (51). P. 29-41[in Ukrainian].

6. Cherep A., Strilets' YE. (2013) Efektyvnist' yak ekonomichna katehoriya [Efficiency as an economic category]. Retrieved from: http://www.economy.nayka.com.ua/?op=1\&z=1727 [in Ukrainian].

7. Stashchuk O., Khomiuk N., Bochko O., Pavlikha N., Demchuk A., Shmatkovska T., Naumenko N. (2020). Economic modeling of sustainable rural development under the condition of decentralization: a case study of Ukraine. Scientific Papers. Series "Management, Economic engineering in agriculture and rural development", 2020. Vol. 20, Issue 3. [In English]. 